\title{
MUHAMMADIYAH NAZHIR ORGANIZATION Analysis of Waqf Management and Development in Cianjur ${ }^{\Omega}$
}

\author{
Cucu Solihah, Dedi Mulyadi and Hilman Nur \\ Faculty of Law Universitas Suryakancana, Indonesia \\ E-mail: cucusolihah2012@gmail.com; dedimulyadi53@gmail.com; hilmannur80@gmail.com
}

\begin{abstract}
Throughout the history of human civilization, waqf has been able to prove its considerable contribution to religion, humanity, economy and society. Waqf management and development brings positive impact on society if it is administered by waqf goal-oriented nazhir, one of which is managed by Muhammadiyah organization. Their assets grows bigger each year by focusing on social program as their main strategy. This study employed normative juridical approach by descriptive analysis. Data source of this research is primary source from interview with the local leaders of Muhammadiyah and waqifs.
\end{abstract}

Keywords: welfare, nazhir, utilization

\begin{abstract}
Abstrak
Sepanjang sejarah peradaban manusia telah mampu membuktikan dahsyatnya wakaf bagi agama, kemanusiaan, ekonomi dan sosial. Pengelolaan dan pengembangan wakaf akan memberikan dampak terhadap kesejahteraan bagi manusia jika dikelola oleh nazhir yang berorientasi pada tujuan wakaf, dan salah satu nazhir yang mendapat kepercayaan yang cukup baik dari masyarakat adalah organisasi masyarakat (ormas) Muhammadiyah, bahkan asetnya setiap tahun terus berkembang dengan programprogram keumatan yang menjadi strategi utamanya. Penelitian ini menggunakan pendekatan normatif yuridis yang berupa analisis deskriptif. Sumber data yang digunakan adalah data primer yang berupa wawancara dengan nadhir pimpinan daerah Muhammadiyah Cianjur, dan para wakif.
\end{abstract}

Kata kunci: kesejahteraan, nazhir, pendayagunaan

\section{Introduction}

Waqf is a part of Islamic philanthropic activity that significantly contributes to people's prosperity due its characteristic which is not only limited for asnaf (recipients) like zakat. The success of waqf management and development strongly depend on nazhir role (waqf administrators) who must be reliable, honest, fair, highly committed and professional. It is also supported by organization high performance approach as the alternative pattern of waqf utilization through optimizing some factors such as management quality, openness and action-oriented, long-term orientation, sustainability and the quality of employees or administrators. ${ }^{1}$

Result of the Research on Competitive Research Scheme entitled: Pola Pendayagunaan Wakaf Oleh Ormas Muhammadiyah Melalui Pendekatan Organisasi Berkinerja Tinggi (OBT) Guna Meningkatkan Partisipasi Masyarakat
Right status of waqf land given by society as wakif (waqf giver) to social and religious institutions automatically only holds right to use without right to disposal since the right of waqf land is drawn out from economic flow. Consequently, any property that has been being waqf cannot be alienated or used for collateral and other economic needs. ${ }^{2}$

Imam as-Shafi'e juxtapose the concept of waqf and the emancipation of slave in which a slave does not belong to the master anymore once they were set free. It is because by giving

Dalam Pembangunan Daerah di Kabupaten Cianjur, No. 105SP2H/PPM/DRPM/II/2016, on February $17^{\text {th }}, 2016$.

1 Andre A. De Wall, 2014, Menjadi Organisasi Berkinerja Tinggi, Jakarta: Ina Publikatama, page 27-29.

2 A.P. Parlindungan,1998, Komentar Atas Undang-Undang Pokok Agraria, Bandung: Citra Aditya Bakti, page 146 
waqf, the wakif no longer own their properties. $^{3}$

Muhammadiyah is one of nazhir organizations. It is religious organization that was established in 1912. As rechtperson, this organization has played its roles along with the existence of Muhammadiyah organization in Indonesia including in regional level, this organization has also managed charity and services.

Muhammadiyah regional leaders as nazhir in running their roles basically try to keep, administer, produce, and manage the result of waqf then distribute it well and fairly to mauquf alaih (waqf recipients). ${ }^{4}$ The position of Muhammadiyah is as nazhir organization. It is based on Article 7 section (3) of Law Number 41 Year 2004 on Waqf.

Another charity and services which is quite successful comparing to other community organizations is the existence of waqf and property council that has function as the means of utilizing waqf from society in order to be empowered by regional leaders. Along with the existence of Law Number 41 Year 2004 on Waqf, Muhammadiyah has run the programs that cannot be separated from waqf land matter; therefore, hopefully, waqf as part of Islamic activities is able to increase people's prosperity. ${ }^{5}$

The breakthrough empowerment of $\mathrm{Mu}$ hammadiyah waqf for the benefit of development and sustainability of waqf objects, is implemented with the establishment of educational institutions starting from basic to higher level, social community (orphanage and nursing home), and the built of infrastructure with high potential economy such as healthy canteen area etc.

3 Ibn 'Abidin, Muhammad Amin, "Hashiyah Radd al-Muhtar 'ala al-Durr al-Mukhtar”, Vol. 4 edition 2, ttp: Dar al-Fikr, page 349; Al-Tarabulsi, Burhan al-Din Ibrahim b. Musa b. Abi Bakr Ibn al-Shaykh 'Ali, al-Is'af fi Ahkam al-Awqaf, Beirut: Dar al-Rai'd al- 'Arabi, page 8 in Siti Mashitoh Mahamood, et.al., "Konsep Wakaf Sebagai Instrumen Pembangunan Hartanah Di Wilayah Pembangunan Iskandar (WPI)", Jurnal Pengurusan JAWHAR, Vol. 1 No. 2, 2007, Putrajaya: JAWHAR, page 3.

4 Thalhah Hasan, "Pemberdayaan Nazhir, Al-Awqaf Jurnal wakaf dan ekonomi Islam", Vol. IV No. 04, January 2011, Jakarta: BWI, page 9

5 Majelis Wakaf dan ZIS PP Muhammadiyah, 2010, Panduan Wakaf, Jakarta: PP Muhammadiyah, page 9.
The interesting phenomenon in Muhammadiyah of Cianjur is that the waqifs comes not only from those who domiciled in Cianjur but also from those whose area of lands or waqf objects are outside the region of Cianjur. Moreover, the waqifs are generally dominated by aghnia from community and also community leaders.

Muhammadiyah attempts to implement the Laws Number 41 Year 2004 on waqf which states that waqf is the legal action of waqif to split and/ or hand over some of his/her possessions to be used forever or in the long term based on the necessaries needs for worship on/ or public welfare by sharia.

\section{Problems}

Based on the background above, the problems are formulated as follows: First, Management and development system of waqf in Muhammadiyah Cianjur; and Second, The hindrances in managing and developing waqf in $\mathrm{Mu}$ hammadiyah Cianjur.

\section{Research Method}

This research uses juridical normative approach through descriptive analysis. The data source comprises primary data which is the interview with Nazhir, the regional leader of $\mathrm{Mu}$ hammadiyah Cianjur and the waqif. Secondary data in form of primary data is legislation, such as Laws Number 41 Year 2004 on waqf management. The data collection technique is taken from Ministry of Religion of Cianjur and also waqf and property council in regional leaders of Muhammadiyah Cianjur along with using data triangulation in analyzing the data. Method of analysis is done by interpretation processes, which tries to pass and capture the meaning of data obtained and then conduct a critical evaluation and presents the alternative view which is more complete and suitable.

\section{Discussion}

Management and Development System of Waqf of Regional Muhammadiyah in Cianjur

History of waqf has given faith to muslim society about the essence of Islamic teaching in 
social aspect. Even nowadays, there has been development of the concept of productive waqf which in turn can improve public welfare in economical aspect. The success lies on the management system, which gives the meaning in the development of productive property for the next generation according to its goal, be it in the form of benefit, service or utilization of the results. ${ }^{6}$

Nowadays, the paradigm of waqf utilization has shifted through productive waqf design and periodically developed especially in Organizational Nazhir. The assessment of productivity waqf design that has comprehensively done, aimed to develop the economic field that is form for the prominence of social community. Waqf, an economic institution for Muslim, that has important role compared to other agenda of Islam, needs to be developed carefully and in a good way to maximize its utilization for Muslim and others. ${ }^{7}$

Waqf Property should be maintained productively aimed to create a chance for profitable strategic sector, such as job vacancy, public services that can improve society economy. ${ }^{8}$ Waqf also called as "economic corporation" is a waqf that has fund for being developed and the profit aimed for Muslim prominence. Thus, waqf is an activity that invests money for future and developing fund productively. ${ }^{9}$ Waqf is formed by a project that has economic benefits for Mus-lim either directly or not. The income of waqf properties and waqf project is for Muslim pro-minence. ${ }^{10}$

Viewing waqf concept as a fund of productive effort to Muslim economic develop-

6 Abdul Hakim, "Manajemen Harta Wakaf Produktif Dan Investasi Dalam Sistem Ekonomi Syari'ah”, Riptek, Vol. 4 No. I1, 2010, Semarang: Bappeda Kota Semarang, page 21.

7 Mohamad Akram B Laldin, "Maqasid Syariah Dalam Pelaksanaan Waqaf", Jurnal Pengurusan Jawhar, Vol. 2 No. 2, 2008, Putrajaya: JAWHAR, page 3.

8 Abdul Hakim, Op.Cit., page 22.

9 Nilna Fauza, "Rekonstruksi Pengelolaan Wakaf: Belajar Pengelolaan Wakaf Dari Bangladesh Dan Malaysia", Universum, Vol. 9 No. 2, July 2015, Kediri: P3M STAIN, page 161.

10 Asmak Ab Rahman, "Peranan Wakaf Dalam Pembangunan Ekonomi Umat Islam Dan aplikasinya Di Malaysia", Shariah Journal, Vol. 17 No. 1, 2009, Kuala Lumpur: Department of Shariah and Economics, Academy of Islamic Studies, University of Malaya, page 135. ment, a new concept namely cash waqf is proposed. Syafi'l Antonio claimed that there are four benefits for cash waqf: ${ }^{11}$ First, The amount of money can be various, thus, those who have less money can start to waqf without waiting for more money gotten. Second, Through cash fund, the asset of waqf can be utilized maximally; Third, It can provide aid to some unstable case flow Islamic institutions; Fourth, Muslim can be more independent in developing syiar and dakwah.

The model of management and development of cash waqf is intended as an effort to make productive fund and cash waqf, then the relatively large cash must be collected which takes realistic and effective ways to mobilize it. $^{12}$

Seeing from the benefits aspect, productive waqf is very potential for development so it is clearly more profitable for people economic empowerment. There are several reasons to make productive waqf as an alternative solution in overcoming community welfare problems. First, People will perceive the benefits of waqf, not only for certain community, especially the benefits is felt by those who are in low level of prosperity. Second, Productive waqf is not only able to be used for a certain means of interest but also as a means of developing people in various fields, such as social security, education, culture, public economy, health and others. Third, Productive waqf is an effort to minimize economic inequality in society because Islam wants the wealth not to circulate among the rich only, but it must be distributed to members of society as a form of goodness that will be received in return for the good, as the Quran said in Surah Al-Zalzalah verse 7:

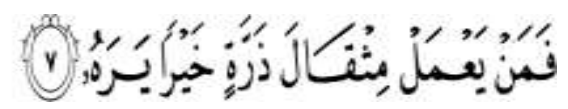

11 Syafi' i Antonio dalam Fajar Hidayanto, "Wakaf Tunai Produktif”, Mukadimah, Vol. XV No. 26, January-June 2009, Yogyakarta: Koordinator Perguruan Tinggi Agama Islam Swasta (Kopertais) Wilayah III, page 18.

12 Fajar Hidayanto, "Wakaf Tunai Produktif", Mukadimah, Vol. XV No. 206, January-June 2009, Yogyakarta: Koordinator Perguruan Tinggi Agama Islam Swasta (Kopertais) Wilayah III, page 28. 
Meaning: So whosoever does good equal to the weight of an atom (or a small ant), shall see it.

In the perspective of community development, the concept of community empowerment is realized when waqf is managed productively. Moreover, comparing productive waqf in terms of a business, it does not just make the property of waqf to be developed but also at the same time it opens some new businesses and open job opportunities. Thus, the function of waqf does not only provide property that can be utilized for all but also it provides job opportunities and empowerment efforts of the weak.

Awareness of the importance of social organization indicates a modern society. Similarly, Muhammadiyah, a mass organization, has implemented structuring the pattern of empowerment and use of waqf by and for organization (union).

Muhammadiyah organization of Cianjur as a nazhir takes account of the waqf impact for organization development. Thus the policy applied through the legality of ownership of all waqf assets of the community belongs to the union which is practically, it is expected that the receipt of waqf property is not on behalf of individual but in the name of a centralized Muhammadiyah union from the center (Muhammadiyah Central Executive)

Muhammadiyah board, region or branch, reported a copy of waqf land certificate to Central Muhammadiyah and the higher board of the Union, so the administrative data of waqf can be done well and nazhir is obliged to report the management of waqf property to Indonesian Waqf Board. ${ }^{13}$

Mostly, the potential of waqf collected by Muhammadiyah are in form of land. It indicates the high level of public's confidence in Muhammadiyah to build educational and social facilities; such as, health schools and orphanages.

13 Majelis Wakaf dan ZIS PP Muhammadiyah, Op Cit., page 49.
Prior to 2000, Muhammadiyah waqf has long been managed by institutions and individuals not unions, but in practice there are still some constraints, which are the lack of understanding and concern of Muslims regarding waqf, inadequate human resources, and the influence of global economy. ${ }^{14}$

Law Number 41 Year 2004 on Waqf provides direction and scope of waqf property, consisting of immovable or movable property including waqf of money which is very flexible in use, not limited to the establishment of social or worship place. Such a legal formulation, obviously a very revolutionary transformation and if it can be realized will have a multiplier effect, especially in relation to the economic empowerment of Muslims. ${ }^{15}$

Strategy to Overcome the Constraints on the Development of Waqf Property in the Regional Leadership of Muhammadiyah Cianjur

The phenomenon of waqf implementation in Regional Leadership of Muhammadiyah Cianjur who receive waqif from within and outside the city to waqf their property seems less balanced with maximum empowerment by nazhir. This is mainly due to the form of waqf objects/ property that are generally represented land (productive and non-productive), the lack of financial capital in the form of finance to build and empower waqf property, despite its sufficient empowerment.

Those constraints are very common, especially those which are managed by community including waqf land utilization. They find it difficult to manage productively along with Islamic law or the given regulation since nazhirs are lack on professionalism and donation for cost management. ${ }^{17}$ It should be noted that the le-

14 Diretorat Pemberdayaan Wakaf, 2006, Perkembangan Pengelolaan Wakaf di Indonesia, Jakarta: Direktorat Pemberdayaan Wakaf, Dirjend. Bimas Islam, Dalam Ahmad Suwaidi, "Wakaf Dan Penerapannya Di Negara Muslim", Economic: Jurnal Ekonomi dan Hukum Islam, Vol. 1 No. 2, 2011, Banyuwangi: Sekolah Tinggi Agama Islam Darul Ulum, page 15.

15 Fahmi Medias, "Wakaf Produktif Dalam Perspektif Ekonomi Islam", Jurnal Ekonomi Islam La Riba, Vol. IV No. 1, July 2010, Yogyakarta: Islamic Economic Studies Program, Faculty of Islamic Studies, Universitas Islam Indonesia, page 70 . 
Chart 1 Potential of Waqf and Its Allotment

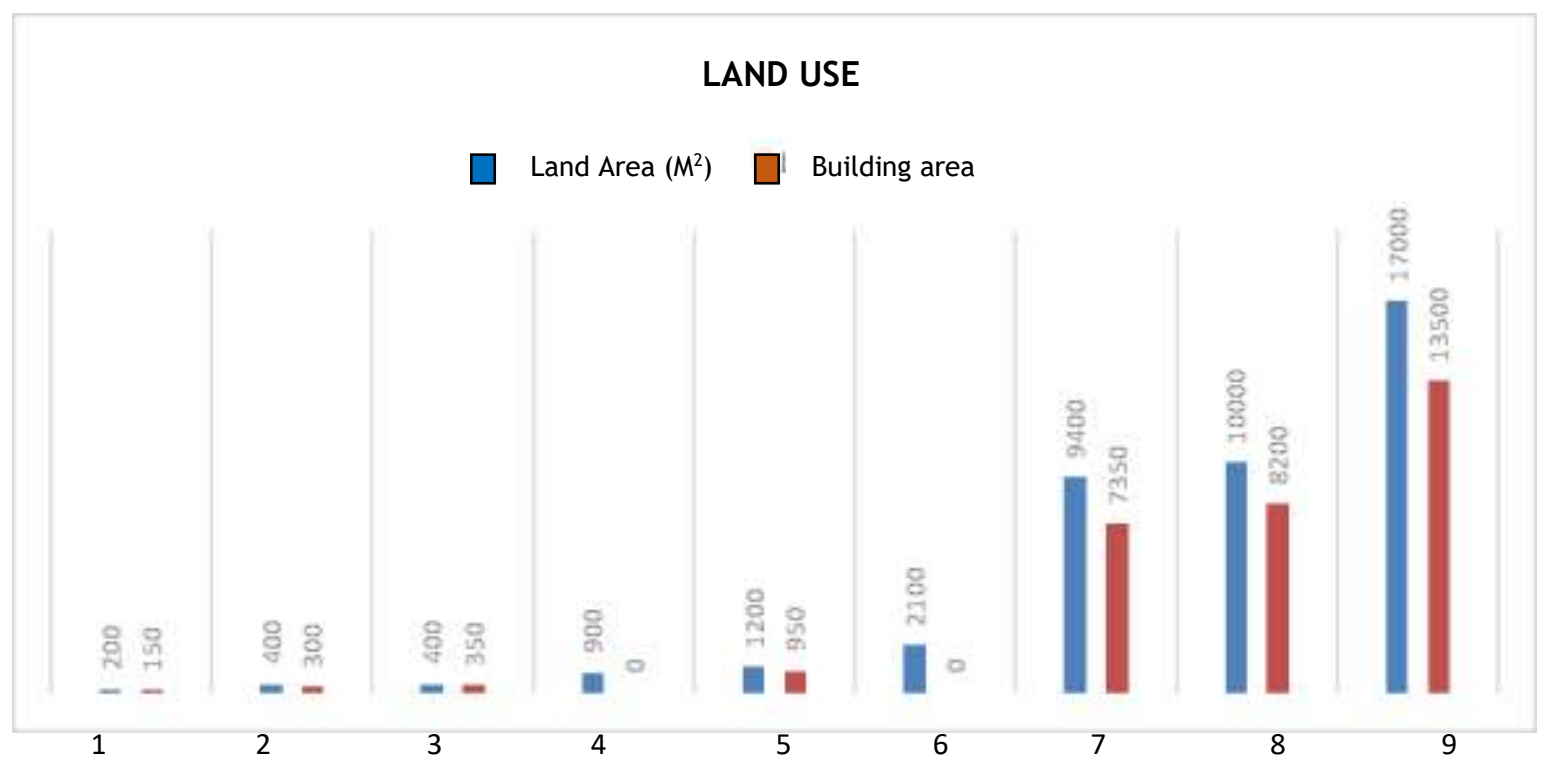

Resource: Data asset of PD Muhammadiyah in Cianjur Regency, 2015. Source from PD Muhammadiyah Cianjur Regency Explanation of Chart: 1. Public Facilities (toilet), 2. House, 3. Madrasah, 4. Funeral, 5. Mosque, 6. Rice Field, 7. Education, 8. School, 9. Mosque and school

gality of waqf deed of pledge could potentially become dispute of land legal status and horizontal conflict. Hence, it requires a regulation of land endowment ownership and other code of conduct. ${ }^{18}$

Waqf empowerment is necessarily considered as "economic redistribution". It means dissemination of wealth from half of a group to anothers by either cash or not. Redistribution also includes public services, such as health and education from one group to others. Thus people experienced material benefit and then those redistribution result in expense. Therefore, prime mover or redistributive agent functions as mediator between redistributive utilization process and redistributive cost. In this case there are three types of redistributive agent: goverment, individual and private institution. ${ }^{19}$ Therefore, waqf can be called as technical term of redistributive mechanism. Cash waqf could become outstanding redistributive mechanism for widely community.

Regarding to this, Muhammadiyah waqf and property council according to qaidah fiqh "evolving and reassure wealth, waqf, and property rights of association also guide the community in doing waqf, grant, infaq, shadaqah and fulfill zakat obligation". Meanwhile their several main functions include: First, Developing. It means make effort, utilize, and manage abandoned association assets. Second, Protecting. It means doing some action to keep, protect, maintain, and solve all of the dispute problems which concerned in association asset such as waqf asset. Third, Guiding. It means to provide direction, training, guidance, instruction, and orientation, about the acceptance, implementation, and maintenance of fixed asset and non fixed asset procedure, also give motivation to community to do waqf.

In terms of effectiveness and eficiency of waqf property utilization, the chief of Muhammadiyah as legal organization gives an authorities to the chief in district, region, and branch to manage waqf by considering suggestion from Muhammadiyah central board. ${ }^{20}$

Strategy development for waqf asset utilization as mentioned above aims to avoid an understanding of abandoned, poor maintained land or land which is not use and convenient with the condition, disposition or the aim of rights giver. ${ }^{21}$ Besides, an implementation of Article 13 Law Number 41 Year 2004 on Waqf is required which gives media for nadzir organiza- 
tion to get guidance from Indonesia waqf board in Cianjur regency. Thus the supervision in managing, developing, and protecting the property of waqf will be realized although its nadzir is Muhammadiyah organization itself.

Developing, protecting, and guiding is a form and implementation of high performing organization concept through development of management quality, openness, action and long term oriented, suistanable and qualified human resources (manager).

\section{Conclusion}

Based on the findings, conclusion is drawn as follows: System of managing and developing waqf in Muhammadiyah Cianjur refers to the organization charity concept by performing qaidah developing and protecting property, waqf, property right of association, and guiding the community in waqf implementation using management and utilization strategy in terms of: First, Worship facilities; Second, Education in building elementary, junior and high school; and Third, Economic aspect by having asset of productive land in the form of rice field and garden. Besides, developing cash waqf to manage waqf lands from community. It is in accordance with qaidah ushul figh which explains that: "Maalaa yatimmulwaajibu illa bihi", means something which causes imperfection of an obligation except with it.

The constraints encountered in managing and developing waqf in Muhammadiyah Cianjur can be seen in people understanding as wakif (the person who donates) in donating their property in form of land. It brings impact on: First, Eneffective waqf asset management is caused by cost to utilize waqf potential; Second, Although legally Muhammdaiyah waqf assets are under the name of association, there are still waqf under the name of individual in Cianjur regency; Third, Effort to legalize process by waqf certficate requires significant cost, handling deed of pledge waqf to National Land Authority which is free of charge is needed through synergy of PRONA program and Fourth, Nazhir Muhammadiyah who have not yet guided by Indonesian Waqf Board in Cianjur regency because its establishment is relatively new in 2016.

\section{Suggestion}

In regards to this the author proposes the following suggestions: First, law enforcement such as local regulation is need especially on waqf functioned as law protection in implementation and utilization of waqf for regional development; Second, government role (ministry of religion and National Land Authority) is necessarily needed to handle waqf land certificate free of charge for community through PRONA program and supported by regent instruction; and Third, An upgrading synergy performance of nazhir organization is required with Indonesian waqf institution for increasing management and utilization pattern of waqf asset. Therefore, it will raise people thrust which lead to upgrade waqf asset utilization function for regional development program in Cianjur regency.

\section{References}

Abidin, Ibn. Muhammad Amin. Hashiyah Radd al-Muhtar 'ala al-Durr al-Mukhtar. Edition 2 Vol. 4. ttp: Dar al-Fikr;

A De Wall, Andre. 2014. Menjadi Organisasi Berkinerja Tinggi. Jakarta: Ina Publikatama;

Ab Rahman, Asmak. "Peranan Wakaf Dalam Pembangunan Ekonomi Umat Islam Dan aplikasinya Di Malaysia". Shariah Journal. Vol. 17 No. 1. 2009. Kuala Lumpur: Department of Shariah and Economics. Academy of Islamic Studies. University of Malaya;

Ahmad Suwaidi. "Wakaf Dan Penerapannya Di Negara Muslim". Economic: Jurnal Ekonomi dan Hukum Islam. Vol. 1 No. 2. 2011. Banyuwangi: Sekolah Tinggi Agama Islam Darul Ulum;

Amin, M Soleh. "Tanah Wakaf dan Status Hukumnya Dalam Perspektif Hukum Agrarian". Jurnal wakaf dan Ekonomi Islam Al-Awqaf. Vol. IV No. 02 July 2011. Jakarta. Badan Wakaf Indonesia;

Arif, Syarifudin. Wakaf Tunai Sebagai Alternatif Mekanisme Redistribusi Keuangan Islam. La-Riba Jurnal ekonomi Islam. Vol. IV No. 1. July 2010. Yogyakarta: Program Studi 
Ekonomi Islam Fakultas Ilmu Agama Islam Universitas Islam Indonesia;

Fauza, Nilna. “Rekonstruksi Pengelolaan Wakaf: Belajar Pengelolaan Wakaf Dari Bangladesh Dan Malaysia". Universum. Vol. 9 No. 2 July 2015. Kediri: P3M STAIN;

Hakim, Abdul."Manajemen Harta Wakaf Produktif dan Investasi Dalam Sistem Ekonomi Syari'ah". Riptek. Vol. 4 No. I1. 2010. Semarang: Bappeda Kota Semarang;

Hasan, Thalhah. "Pemberdayaan Nazhir. Al-Awqaf Jurnal wakaf dan ekonomi Islam". Vol. IV No. 04. January 2011. Jakarta: BWI;

Hidayanto, Fajar. "Wakaf Tunai Produktif". Mukadimah. Vol. XV No. 26. January-June 2009. Yogyakarta: Koordinator Perguruan Tinggi Agama Islam Swasta (Kopertais) Wilayah III;

Huda, Nurul. dkk. "Akuntabilitas Sebagai Sebuah Solusi Pengelolaan Wakaf". Jurnal Akuntansi Multiparadigma. Vol. 5 No. 3. December 2014. Desember 2014. ISSN 2086-7603. Malang: Universitas Brawijaya;

Mahamood, Siti Mashitoh. dkk. "Konsep Wakaf Sebagai Instrumen Pembangunan Hartanah Di Wilayah Pembangunan Iskandar (W PI)". Jurnal Pengurusan JAWHAR. Vol. 1 No. 2. 2007. Putrajaya: JAWHAR;

Majelis Wakaf dan ZIS PP Muhammadiyah. 2010. Panduan Wakaf. Jakarta: PP Muhammadiyah;

Medias, Fahmi. "Wakaf Produktif Dalam Perspektif Ekonomi Islam". Jurnal Ekonomi Islam La_Riba. Vol. IV No. 1 July 2010. Yogyakarta: Islamic Economic Studies Program, Faculty of Islamic Studies Universitas Islam Indonesia;

Mohamad Akram B Laldin. "Maqasid Syariah Dalam Pelaksanaan Waqaf". Jurnal Pengurusan Jawhar. Vol. 2. No. 2. 2008. Putrajaya: JAWHAR;

Muljadi dan Widjaya dalam Jaih Mubarok. 2008. Wakaf Produktif. Bandung: Simbiosa Rekatama Media;

Parlindungan, A P.1998. Komentar Atas UndangUndang Pokok Agraria. Bandung: Citra Aditya Bakti. 